\title{
obituary
}

\section{Sir Edward Salisbury}

Sir Edward James Salisbury, CBE, FRS, who died on 10 November 1978 at the age of 92 , was one of the best known British botanists of his generation.

He was born on 16 April 1886 at Limbrick Hall, Hertfordshire, his father, J. Wright Salisbury, being a member of a distinguished family long resident in the area. He was educated at University College School and then at University College, London, which he entered as an undergraduate in 1905 , graduating with an honours degree in botany in 1908. He stayed on as a research student, from 1910 onwards as Quain Student; moved to East London College in 1914 as senior lecturer in botany, and returned to University College as lecturer in 1918. In 1924 he was made university reader in plant ecology, and succeeded F. W. Oliver as Quain Professor in 1929, retaining this post until he was appointed director of the Royal Botanic Gardens, Kew, in 1943. He retired from the directorship in 1956 at the age of 70 . $\mathrm{He}$ was elected Fellow of the Royal Society in 1933, was awarded its Royal Medal in 1945, and served as Biological Secretary from 1945 until 1955 . He was made CBE in 1939 and was knighted in 1946.

Salisbury showed an interest in plants at quite an early age. By his 15 th birthday, when one of his presents was a copy of Hooker's Student's Flora. he had a garden plot in which wild plants he had collected were labelled with their Latin names, had formed a private herbarium and could identify most of the flowering plants of Hertfordshire. He went to University College during an important period of change in attitude towards the scientific study of plants.

The professor of botany was F. W. Oliver, and A. G. Tansley was a lecturer on his staff from 1893 until his return to Cambridge in 1907. Both had been much influenced in their research and teaching by the striking advances in palaeobotany of the few previous decades. Just before the turn of the century, however, Oliver embarked on his studies of coastal vegetation and Tansley became deeply interested in the 'ecological' and physiological aspects of plant geography as expounded by Warming and Schimper respectively. They had been increasingly dissatis- fied with the almost exclusive attention to comparative morphology and anatomy which still characterized much botanical teaching and welcomed the ecological emphasis on the plant as a functional whole.

Salisbury was immediately attracted by Oliver's lectures and especially by his field excursions to the north Norfolk coast and elsewhere. After graduation he elected to work with Oliver and two joint papers appeared in 1913, one being a lengthy general account of the ecology of Blakeney Point. Meanwhile his ecological interests were extending to problems of inland vegetation and especially of woodlands, and his now classic studies of variations in the woodland light climate with season and with stage in the coppice-cycle, and their effects on the ground flora, soon attracted attention. He was already laying the foundations of his reputation as a leading academic botanist, and his appointment to the Quain Chair in 1924 greatly increased his influence.

This was early exerted through the series of text-books written in collaboration with F. E. Fritsch. An Introduction to the Study of Plants was published in 1914 by G. Bell \& Sons and was immediately successful in encouraging the consideration of plants as living and functioning wholes rather than as assemblages of organs, tissues and cells. The last of the famous 'Fritsch \& Salisbury' series was Plant Form and Function (1938).

While still a research student Salisbury was invited to join the British Vegetation Committee, set up in 1904 to coordinate current work on the survey and study of British vegetation and converted in 1913 into the British Ecological Society. Salisbury was a founder member of the Society and was invited to join its council and to become hon. secretary in 1915, an office he held until 1931. He was elected president for the two years 1929-30.

His presidential address, 'The biological equipment of species in relation to competition' (1929), reveals very clearly how far British ecology, with its primary aim of understanding why plants of some species but not of others grow in a given area, had come to differ from continental ecology with its largely floristic interest and its emphasis on the description and classification of plant communities. Certainly Salisbury was relatively little interested in plant communities as such. His main concern throughout his life was with those features of individual plant species that were most relevant to survival in a given environment and against given competitors, and in particular those that could readily be assessed quantitatively. The best of his books-The Reproductive Capacity of Plants (1942) and Weeds and Aliens (1961) - and large numbers of papers in scientific journals, examine the survival-value of features of seed-production, or of vegetation multiplication and spread, in species of different habitats. They are packed with original data, especially of counts and weights of seeds produced by various species in various circumstances. Eleven of the fifteen papers published during the final ten years of his life are of this kind and the last of all, appearing in the year of his death at 92, included a table of estimated annual production of seeds by 49 different weed species 'based upon my own observations from random samples.'

It is relevant to reflect that Professor J. L. Harper's important book, The Reproductive Biology of Plants, is in many ways a continuation of The $R e$ productive Capacity of Plants, with a successful elucidation of many points left unexplained by Salisbury but with a considerable widening of scope and a far greater emphasis on experimentation. Characteristically, however, Salisbury had perceived many of what were still the outstanding problems in 1977.

Early in his career Salisbury became a member of the Royal Horticultural Society and was for many years a vicepresident. He took great delight in gardening and after his marriage developed a notably attractive and botanically very interesting garden at his home Willow Pool, Radlett. The Living Garden, or The How and Why of Garden Life, a skilful popular exposition of the scientific basis of horticulture appeared in 1945. It was immensely successful and led to the award of the Veitch Memorial Gold Medal of the RHS that same year, and he later received the society's Victoria Medal of Honour. His appointment to Kew was a fitting climax to his career.

Clear-headed, self-confident, determined and articulate, Salisbury was very much a committee man and served on innumerable councils, committees, delegacies and visiting groups. He was governor of several colleges and research institutions and a successful 
chairman of many important public bodies. He was short of stature, lively and friendly in manner, but perhaps rather too fond of indulging his delight in lengthy exposition. He was an able administrator. In the later stages of his career, however, he spent much time on his outside commitments.

In 1917 Salisbury married Mabel Elwin-Coles, who died in 1956 after a long illness. There were no children.

A. R. Clapham

\section{T. Rajagopal}

Professor Cadambathur Tiruvenkatacharya Rajagopal, a mathematician of considerable standing in India, and solely responsible for the survival in Madras of the Ramanujan Institute, died on 25 April 1978. Even more, perhaps, than his numerous original contributions to mathematics and its history (which were substantial by any standards), it is his devotion to the cause of mathematics in India and to the survival of the Institute (which he served in various capacities from 1951 to 1971) which made him a unique figure in an important period of the history of Indian science, deserving to be remembered by future generations of Indian scientists.

C. T. Rajagopal was born on 8 September 1903. His father, Cadambathur Tiruvenkatacharya, was in the judicial service of the Madras Presidency (now Tamil Nadu). His early education was in Madras; he took his Master's degree in the Madras Presidency College (where many of the most distinguished scientists of India, including Sir C. V. Raman, have been students). There he soon came under the influence of Professor K. Ananda Rau, himself a mathematician of great distinction, who had been G. H. Hardy's student and Ramanujan's contemporary in Cambridge. Ananda $\mathrm{Rau}$ is well known and remembered for his valuable contributions to the theory of Tauberian theorems, function-theory and the theory of Dirichlet series; and his tastes and interests were decisive for the orientation of Rajagopal's future scientific career.

After graduating from the Presidency College, Rajagopal joined the Madras Christian College as a lecturer. In 1951, T. Vijayaraghavan, on his appointment as director of the Ramanujan Institute, invited him to join its faculty; the story of Rajagopal coincides with that of the Institute for the following twenty-five years.

The Ramanujan Institute was founded in 1951 as a private institution by the late Sir Alagappa Chettiar, a noted philanthropist of South India, as 'a small remembrance of a great man (Srinivasa Ramanujan). Its first director, T, Vijayaraghavan, was perhaps the most talented among G. H. Hardy's former students; he died at a comparatively early age in 1955; Rajagopal took over the directorship from him. Already at that time the financial status of the Institute seemed shaky, since Alagappa Chettiar's fortune was melting away; T. Vijayaraghavan's family was left unprovided for, and an appeal to the Prime Minister (the late Jawaharlal Nehru) had to be made in order to rescue them from utter poverty.

In April 1957, when Alagappa Chettiar died, the fate of the Institute hung in the balance; Rajagopal wrote to one of us (S.C.) that the Institute 'will cease to exist on the first of next month,' whereupon the addressee wrote to the Prime Minister, explaining the origin of the Institute and the seriousness of its condition. Nehru's prompt answer was refreshing: 'Even if you had not put in your strong recommendation in favour of the Ramanujan Institute of Mathematics, I would not have liked anything to happen which put an end to it. Now that you have also written to me on this subject, I shall keep in touch with this matter and I think I can assure you that the Institute will be carried on.'

And it was; but haltingly and precariously for the next twelve years. The responsibility for the Institute was divided between the U.G.C. (the federal University Grants Commission) and a reluctant University of Madras. There is no doubt that the Institute would not have survived had it not been for Rajagopal's continuing year after year with an uncertain appointment and often as the sole 'permanent' member of the Institute. In 1963 the future of the Institute and Rajagopal's own means of survival were so much in doubt that he wrote us in the following terms: 'In twenty-one years of service as a teacher (of which the first year was spent in Annamalai University and the rest in Madras Christian College), my salary rose from Rs. 100 p.m. to about Rs. 240 p.m. and earned for me a provident fund of nearly Rs. 8,000 . In the next twelve years of my service, in the Ramanujan Institute, my salary scale was Rs.500 - 50 - 800 until I was made a professor with effect from 1st March 1962 on Rs. 850 p.m. in the present Madras University scale of Rs. $800-50-1,250$. However, my service in the Institute has left me with no savings and no retirement benefits. Thus, after a professional life of thirty and odd years, I find myself without the means to live in complete independence. . .
But Rajagopal did continue to serve the Institute for the following six years, and at long last, in August 1967, the Ramanujan Institute was finally adopted by the University of Madras, and in July 1969 a new director was appointed. Its subsequent fortunes do not concern us here; but this left Rajagopal with no pension; not a single naya paisa (the new half-penny), as he himself wrote; the undersigned, singly or jointly, must have written dozens of letters to various authorities during the years 1963-1978 to secure for him a modest stipend of Rs.500 p.m.

Despite such administrative and personal worries and frustrations, and without ever an opportunity for visiting any centre of mathematics in Europe or the United States, Rajagopal maintained an unabated output of competent, worthwhile mathematical research, well appreciated by coworkers in his favourite fields, chiefly Tauberian theorems and entire functions. In the latter part of his life, he became actively interested in the history of medieval Indian mathematics, to which he contributed a number of important papers, partly in collaboration with others; the last one, a joint article with $\mathbf{M}$. $\mathbf{S}$. Rangachari, appeared only a few weeks before Rajagopal's death, in C. Truesdell's well-known Archive for History of Exact Sciences, vol. 18, pp. $89-102,1978$. There it is shown that a number of power-series expansions for trigonometric and inverse trigonometric functions, discovered in the 17 th century by Gregory, Newton and Leibniz (and independently, about the same time, by the Japanese Seki), had been known to Kerala mathematicians more than a century before.

Professor C. T. Rajagopal is survived by his wife, Mrs. Rukmini Rajagopal (now living in straitened circumstances, it must be pointed out, due to the lack of provision for a pension fund at the Ramanujan Institute). Tragically, Rajagopal's death occurred just as a grant had been approved to support the continuation of his and M. S. Rangachari's historical investigations, which were to appear eventually as a monograph on Kerala mathematics.

India may well have produced mathematicians of greater versatility and depth than C. T. Rajagopal, and will, one hopes, produce more such in the future; but none has served the cause of mathematics more selflessly nor with greater devotion. As both of us happen to have been personally associated, for many years, with this modest and talented man, we find it fitting that his long years of service be placed on record.

S. Chandrasekhar André Weil 